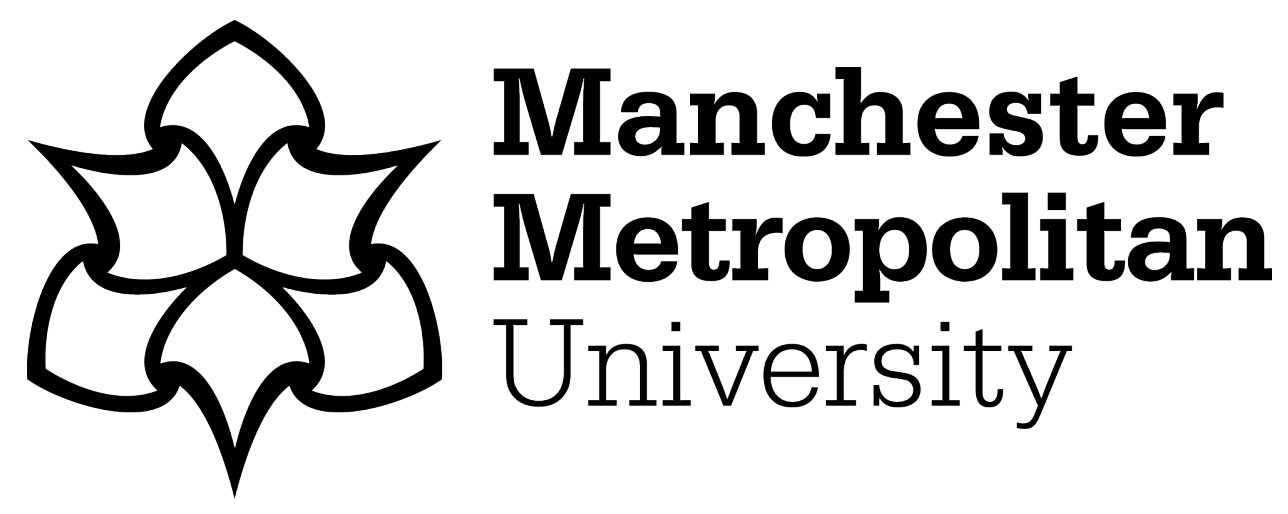

Banna, H, Hassan, MK, Ahmad, R and Alam, MR (2022) Islamic banking stability amidst the COVID-19 pandemic: the role of digital financial inclusion. International Journal of Islamic and Middle Eastern Finance and Management, 15 (2). pp. 310-330. ISSN 1753-8394

Downloaded from: https://e-space.mmu.ac.uk/628900/

Version: Accepted Version

Publisher: Emerald

DOI: https://doi.org/10.1108/IMEFM-08-2020-0389

Usage rights: Creative Commons: Attribution-Noncommercial 4.0

Please cite the published version 


\title{
Islamic Banking Stability Amidst the COVID-19 Pandemic: The Role of Digital Financial Inclusion
}

\author{
(Corresponding Author) \\ Ungku Aziz Centre for Development Studies \\ Faculty of Economics and Administration \\ Universiti Malaya (UM), Kuala Lumpur-50603, Malaysia \\ E-mail: banna@um.edu.my \\ ORCID: http://orcid.org/0000-0002-6902-8525 \\ M. Kabir Hassan
Graduate Coordinator for Ph.D. Program in Financial Economics
Professor of Finance and
Hibernia Professor of Economics and Finance and
Bank One Professor in Business and
Hancock Whitney Chair Professor of Economics
University of New Orleans
New Orleans, LA 70148, USA
Email: mhassan@uno.edu
ORCID: http://orcid.org/0000-0001-6274-3545 \\ Department of Economics and Finance
}

\author{
Rubi Ahmad \\ Department of Finance and Banking \\ Faculty of Business and Accountancy \\ Universiti Malaya (UM), Kuala Lumpur-50603, Malaysia \\ E-mail: rubi@um.edu.my \\ Md Rabiul Alam \\ Department of Language and Literacy Education \\ Faculty of Education \\ University of Malaya, Kuala Lumpur-50603, Malaysia \\ E-mail: rabiulalam_84@yahoo.com
}

\section{Structured Abstract}

Purpose: This study explores the role of Digital Financial Inclusion (DFI) in stabilizing the Islamic banking sector amidst the current COVID-19 pandemic.

Design/methodology/approach: This study has employed the Panel-Corrected Standard Errors (PCSE), Two-Stage Panel Least Squares-Instrumental Variables (2SLS-IV), and TwoStep System Generalised Method of Moments (2SGMM) dynamic panel estimation method to investigate the DFI-Islamic banking stability nexus using an unbalanced panel data of 65 Islamic banks from six countries over the period 2011-2020.

Findings: The result suggests that greater implementation of DFI promotes Islamic banking stability, which reduces the default risk of the banks in the studied region. Consequently, 
incorporating DFI into the Islamic banking sector encourages inclusive economic growth that can keep the financial sector sustainable even in a crisis period like the current COVID-19 pandemic.

Originality: Unlike previous studies, we have focused mainly on DFI and the Islamic banking sector. This is one of the first to explore how DFI contribute to the stability and productivity of the Islamic banking sector during the pandemic. Also, this study provides fresh evidence on how the supply and demand side of DFI impact Islamic banking stability.

Keywords: Digital financial inclusion; FinTech; Islamic banks; Banking stability; COVID19.

JEL: E44, F65, G21, G28.

\section{Introduction}

Does DFI promote Islamic banking stability amidst the COVID-19 pandemic? This question raises many issues to explain. Undoubtedly, the recent COVID-19 outbreak has disrupted all sectors of human civilization, prompting a frantic search of global academics and policymakers for an effective solution to surmount its damages. Although the pandemic affected all economic sectors, the global financial sector is the worst hit, resulting in an unendurable burden (Baldwin and di Mauro, 2020) due to the sector's pertinent influence (direct and indirect) on daily human activities (Banna et al., 2020a). As a result of the pandemic, measures such as social distancing, lockdown, and quarantine were put in place, which halted people's everyday activities and triggered an economic shutdown (Atkeson, 2020). The effect of the economic shutdown is pronounced in many sectors like tourism, manufacturing, sports and recreation, banking, etc. Of all these, the banking sector appears to be the most affected, as it represents the channel through which most people's financial affairs are conducted (Banna and Alam, 2020).

Moreover, the economic stability of a nation is dependent on the stability of the banking sector. Hence, it is pertinent to maintain the stability of the banking industries (conventional and sharia-based) to ensure smooth global financial sustainability (Banna et al., 2020a; Salami et al., 2021). However, our focus of the study is restricted to the Islamic banking sector due to 
its proven stability and resilience history after the 2007-09 Global Financial Crisis (GFC), which paralyzed the global economy, especially the banking industry (Ahmed et al., 2015). Islamic banking was able to surmount its financial loss and retain its stability following the GFC, owing to the nature of its instruments, efficient operation, and innovative products in the form of financial inclusion (FI) (Kim et al., 2020; Yu et al., 2018; Ahmed, 2010; Kayed and Hassan, 2011). Moreover, through FI, Islamic banks provided financial services to the unbanked population who are opposed to the formal financial institution due to religious concern (Naceur et al., 2017). Therefore, Islamic banking remains a better choice for these populations, as it follows the Islamic injunctions in its financial services and offers them salvation in this life and hereafter. Given the contribution of Islamic banks to human welfare, it is only natural that their stability and development should be prioritized. Hence, the proper application of DFI should be carefully considered to ensure the stability of Islamic banking. It represents an updated phase of FI, which has been instrumental in stabilizing Islamic banking during and after the GFC (Ahmed et al, 2015).

Digital financial inclusion bridges modern innovative technology and conventional FI, and therefore seeks to ease banking operations by availing remote access to financial services through an electronic device (e.g., smartphone, laptop, iPad, tablet, etc.) with an internet connection (Manyika et al., 2016; Gabor and Brooks, 2017). Since the pandemic has imposed an embargo on people's physical movement, the banking sector can rely on DFI for its smooth financial operations. Besides, the movement restriction due to the pandemic offers the banking sector an opportunity to fully implement digital financial services as done by many banks in the world (Ellis, 2020). In a bid to maximizing their profit, several conventional banks have started implementing digital financial services in their banking operations, which yielded a positive outcome. Consequent to the successful application of DFI in several countries (e.g., Kenya, Tanzania, etc.), the Chinese authority has considered restructuring its non-bank 
financial sectors under the label 'DFI' (Knaack and Gruin, 2020). In this regard, the Islamic banking sector is not unreceptive; instead, it goes a step further by strengthening its DFI, profiting from its experience of post-GFC (Banna and Alam, 2020; Ahmed et al., 2015). Therefore, it is expected that the execution of DFI in the Islamic banking sector in a proper way would bring out its stability amidst the COVID-19 pandemic.

Despite the importance of the application of DFI in the Islamic banks, empirical studies are very scarce to investigate the impact of DFI on Islamic banking stability. A handful number of recent studies (e.g., Van et al. 2020; Banna et al. 2020a; Ahamed and Mallick, 2019; and Banna and Alam, 2020) have empirically examined the role of FI (not DFI) on both conventional and Islamic banking stability. However, few other studies like Ozili (2018), Koh et al. (2018), Arner et al. (2018), and Siddik and Kabiraj (2020) had explained the importance, prospects, threats, challenges, and recommendations of DFI. Although a positive effect of DFI on banking stability in general has been reported by the recent study of Banna (2020), DFI might also bring an adverse impact on financial stability due to extreme level of financial innovations (Mani, 2016), thus exposing the financial institutions to attacks, such as cyberattacks, data theft, account hacking, card cloning, money laundering, etc. Both the good and bad sides of FI and DFI raise the question of whether the proper application of DFI will promote stability of the Islamic banking sector amidst the COVID-19 pandemic or not. Thus, this study examines the impact of DFI application on the stability of the Islamic banking sector amidst the pandemic.

The study will contribute to the Islamic banking and FI literature in several ways. First, existing studies (as discussed in the preceeding paragraph) have primarily focused on the relationship between FI and banking stability as well as the importance of DFI from the theoretical perspective. This study has, however, empirically investigated the role and importance of DFI on Islamic banking stability. Second, the extant literature (e. g., Ahamed 
and Mallick, 2019, Van et al., 2020) have created a Financial Inclusion (FI) index, but this study has developed a digital financial inclusion (DFI) index using demographic and geographic penetrations as well as demand-side and supply-side penetrations. Third, this current study is hoped to promote the rapid application of DFI in the Islamic banks, as it will help governments in the effective implementation of social distancing measure to curb the spread of COVID-19 while promoting banking stability. Finally, this study uses the latest available DFI data of Islamic banks from six countries and deploying series of econometric methods to test the validity of the main findings and shows how the proper implementation of DFI facilitates Islamic banking stability during financial threats like the current pandemic.

In this regard, this study has utilized an unbalanced panel data of 65 Islamic banks from 6 countries from 2011 to 2020. Data have been extracted from the databases of Orbis Bank Focus (OBF), Global Findex, and Financial Access Survey (FAS). The Panel-Corrected Standard Errors (PCSE), Two-Stage Least Square-instrument variable (2SLS-IV) and TwoStep System Generalised Method of Moments (GMM) dynamic panel estimations are used to analysis the data. The empirical evidence confirms a positive association between DFI and Islamic banking stability by reducing the default risk of the banks in the sample countries. Thus, Islamic banks with an inclusive digital finance services would contribute to sustainable economic growth, which is essential in ensuring financial sustainability during crisis periods like the COVID-19 pandemic.

The remainder of this study is ordered in the following sequence: Section 2 reviews the available relevant literature; methodology and the data sources have been elucidated in Section 3; Section 4 illustrates the findings and their analysis while concluding remarks along with policy implications have been stated in Section 5.

\section{Literature review}

A. A Review of the Prevailing Literature 
Using the fundamental principles of Islamic Shariah, Islamic banking has enjoyed significant growth over the years. However, unlike its conventional counterpart, Islamic banking has some unique characteristics, including its sharing of profit and loss with its customers, offering of the interest-free transaction, and disapproval of trade transaction involving unethical and unlawful businesses, such as gambling, pornography, alcohol, etc. (Thaker et al., 2020). As a result of the contribution of these unique features towards the betterment of society, Islamic banking has been reckoned as the leading banking sector globally and continues to improve in all its activities (Imam and Kpodar, 2016; Imam and Kpodar, 2013) by increasing its profits to maintain its integral stability (Hassan and Bashir, 2003). Consequently, Islamic banking had remained resistant against any kind of shock during and after any financial crisis (Mirakhor, 2008), as evident in its survival following the GFC (Hassan and Dridi, 2010). Furthermore, the Islamic banking sector was observed to be resilient following its survival during the crisis by introducing innovative products in the form of FI (Banna et al., 2020a).

Islamic banks are advancing further technologically by incorporating DFI, which promotes the banking sector's stability. According to Ozili (2018), the proper implementation of DFI in the banking and other financial institutions can bring a revolutionary change that will spur financial growth and stability, consequently benefiting all classes of people, including the underprivileged, rural and poor. Through the full-fledged implementation of DFI, the complete execution of FI will be made possible (Banna and Alam, 2020). In this regard, Siddik and Kabiraj (2020) in their study showed that the application of DFI in the financial sector facilitates the expansion of FI and enhances financial growth and stability, which benefits the poor via poverty eradication (Hassan et al., 2018). According to Manyika et al. (2016), DFI is an innovation that eliminates the need for physical presence at financial institutions. Instead, it can be enjoyed virtually or remotely through an electronic device connected to the internet, which positively impacts banking performance and stability. Furthermore, proper execution of 
DFI facilitates the formalization of informal businesses, which will contribute to the overall development of a country. When informal business institutions are registered, the government can easily collect their taxes due to their records in the database (Klapper et al., 2019).

The application of DFI requires a smartphone with an internet connection, through which people can be transformed into the cashless realm. Over the years, the implementation of DFI has spread rapidly within the financial sector since almost $50 \%$ of the population from developing countries own mobile phones (World Bank Group, 2013). Realizing its importance and advantages, more than 80 countries across the world had inculcated DFI into their financial services, thus improving the country's welfare and overall development (Pénicaud and Katakam, 2019). As DFI innovation is still relatively new in the financial sector, especially in banking, studies on its impact on banking stability (particularly Islamic banking) are scarce. However, few studies have indicated the effect of FI on banking stability. Utilizing the data of 3071 Asian banks from 2008 to 2017 and by deploying the GMM approach, a recent empirical study by Van et al. (2020) showed that a higher level of FI significantly contributes to banking stability and ensures greater bank resilience through reduction of cost, augmentation of revenue and expansion of market share. Hence, the execution of FI can boost banking stability and ultimately promotes banking efficiency and financial sustainability (Rashid et al., 2017).

Considering 32 countries' 154 Islamic banks from 2011 to 2017, the study of Banna et al. (2020a) has investigated the relationship between FI and Islamic banking efficiency in the post-GFC by using techniques like Simar-Wilson double bootstrapping and DEA as well. Their study has found that FI has a great influence on Islamic banking efficiency. It also revealed that Islamic banks with proper implementation of FI were more capable of overcoming the aftermath of the GFC. Another empirical study by Banna and Alam (2020) showed that Islamic banks in Malaysia, Bangladesh, Qatar, Tunisia, Sudan, Iraq, Mauritia, and Afghanistan have been performing efficiently after the GFC. FI was considered to key factor. The study also 
found that the GDP growth of those countries is positively associated with the proper application of FI in the Islamic banking sector. Besides, the study, based on international evidence of 2635 banks from 86 countries over the period 2004-2012, of Ahamed and Mallick (2019) revealed a very positive and significant relationship between banking stability and FI. The study also found that a higher level of FI ensures a greater level of banking stability.

Moreover, the studies of Beck et al. (2014) and Neaime and Gaysset (2018), which are based on the bank data of African and Mena countries, respectively, showed that proper application of FI facilitates a bank's stability. In the recent studies on the ASEAN countries, Banna and Alam (2021a) and Banna and Alam (2021b) highlighted the positive role of DFI on the region's banking stability. Similarly, using single-country data, Banna (2020) showed the general impact of DFI on banking stability. Although these studies reported a positive and significant effect of DFI on banking stability, they are observed from the perspective of conventional banks. Senou et al. (2019) conducted an empirical study analysing the data from the West African region to examine the impact of digital finance on the application of FI. The study concluded that to accelerate banking stability and overall banking performance of that region, the proper application of DFI should be considered, as it enhances regulatory control over financial activities (Naumenkova et al., 2019). Moreover, the study of Moufakkir and Mohammed (2020) indicated that FI and DFI are very closely associated in the context of the Islamic banking sector. However, DFI represents a better choice due to its technological advantages.

In reckoning the undeniable impact of DFI application and keeping pace with the demand of age, Islamic banks worldwide have commenced the digitalization of their activities via DFI (Hasan et al., 2020; Knaack and Gruin, 2020). However, most empirical studies have only investigated the role of FI on banking stability, with mixed results being reported. Moreover, although a few studies have investigated the role of DFI on conventional banking 
stability in general, studies on its impact on Islamic banking stability are scarce. This may be attributed to the newness of DFI in the Islamic banking sector, as it is still being developed. Thus, considering Islamic banks' data from six countries, this study investigates the impact of DFI application on Islamic banking stability amidst the COVID-19 pandemic.

\section{B. Hypothesis development}

Extant literature evidenced that DFI exhibits both positive and negative impacts. On the one hand, with the proper implementation of DFI, formal financial services will access more people, thus promoting their saving culture. Moreover, as a result, banks will also be financially stable, thereby contributing to the country's overall financial development. On the other hand, however, on the flip side, more digitalized financial services might lead to unauthorized financial transactions, account hacking, card cloning, etc. Nevertheless, the advantages of DFI implementation outweigh its disadvantages. Hence, this present study proposes the following hypothesis:

Digital financial inclusion positively impacts Islamic banking stability.

\section{Data and Methodology}

This paper mainly examines whether DFI can confer stability to the Islamic banking sector amidst the COVID-19 pandemic. To find an answer to those above, using existing data, we examined the empirical link between DFI and Islamic banking stability before the pandemic. Hence, this section provides the sources of data considered for this study along with various methodological techniques deployed here.

\subsection{Data}

The study has only taken data of the Islamic banking industry considering its significant contribution towards the economy of a country as its banking asset worth of nearly USD $1.56^{1}$

\footnotetext{
${ }^{1}$ Taken from the IFSB Stability Report 2019
} 
trillion as well as its sustainability during the GFC (Banna et al., 2020a). Besides, this sector is gradually initiating DFS (Banna et al., 2020a) and updating its existing services to facilitate their wider outreach. Moreover, the current COVID-19 pandemic encourages the rapid and full-fledged execution of DFS to retain countries' economic flow stable. Considering all those above, this study initially considered 13 countries $^{2}$ as they hold nearly $95 \%{ }^{3}$ of total Islamic banking assets. However, due to the unavailability of DFI data, our final sample was limited to onle 6 countries; Bangladesh, Qatar, Indonesia, Pakistan, Malaysia, and Sudan, with the sole objective of investigating the link between Islamic banking stability and DFI.

Primarily, this study chose the annual data of 66 Islamic banks of six countries. Nonetheless, due to scarcity of data, our final sample was reduced to 65 Islamic banks with unbalanced panel data from 2011 to 2020 . Nevertheless, this timeframe was considered, as the DFI data is available mainly from 2011 onwards. The detailed sample selection procedure and the breakdown of the sample size are reported in Table I. The table further revealed that Malaysia's Islamic banks constitute the highest portion (26\%), followed by Sudan (23\%) and Indonesia (17\%).

\section{PLEASE INSERT TABLE I HERE}

For this study, different sets of data have been extracted from different databases. For instance, DFI data have been taken from the IMF Financial Access Survey (FAS) and the World Bank Global Findex databases, bank-specific data are from the Bureau van Dijk Orbis BankFocus database, data for macroeconomic variables are from the World Development Indicators (WDI), and instrumental variable are from prevailing studies.

\subsection{Methods}

\subsubsection{Banking Stability}

\footnotetext{
${ }^{2}$ Brunei Darussalam, Turkey, Qatar, Saudi Arabia, Indonesia, Bangladesh, Kuwait, Malaysia, Bahrain, Iran, Pakistan, the United Arab Emirates, and Sudan

${ }^{3}$ Taken from the IFSB Stability Report 2018
} 
Following Yin (2019), this study has considered sharp ratio as a proxy for Islamic banking stability which is as follows:

$$
\text { Sharp ratio } i t=\frac{R O A E_{i t}}{\sigma(R O A E)_{i t}}
$$

Where, $R O A E_{i t}$ and $\sigma(R O A E)_{i t}$ are the return on average equity and the 3-year rolling standard deviation of ROAE of bank $i$ in year $t$, respectively. The ratio implies that the higher (lower) the ratio, the higher (lower) the Islamic banking stability (i.e., less (more) risk-taking).

Besides, this paper has also employed Z-score, the most used proxy for Islamic banking stability in the literature, which has been used by Banna and Alam (2021c), Kim et al. (2020), Banna (2020), and others to measure bank stability. Equation in the following shows the Zscore measurement:

$$
Z-\text { score }_{i t}=\frac{R O A A_{i t}+E Q T_{i t}}{\sigma(R O A A)_{i t}}
$$

Where the return on average assets is shown by $R O A A_{i t}$, the equity over total assets ratio is by $E Q T_{i t}$ and $\sigma(R O A A)_{i t}$ represents the 3-year rolling standard deviation of ROAA of bank $i$ in year $t$. The natural logarithm of both the sharp ratio and the Z-score has been used to mitigate the possible skewness.

\subsubsection{Digital Financial Inclusion Index}

This study measures a comprehensive DFI index to see the link between Islamic banking stability and DFI. Although constructing a DFI index or DFI proxies proved difficult because of massive unavailability of required data, we have measured an index of DFI using the data available on the FAS and each country's central bank. In this regard, variables that are merely associated with digital financial activities such as mobile and electronic services that can be accessed remotely, have been considered. Furthermore, since we have excluded the countries without available data, missing values have significantly been reduced. 
For a comprehensive index measurement, this paper utilized the supply (access/outreach) and the demand-side (usage) variables based on the geographic and demographic penetrations. Although previous studies (e.g., Banna et al., 2020a; Banna and Alam, 2020; Ahamed and Mallick, 2019) have attempted to construct an index of FI or standalone proxy of DFI, a comprehensive DFI index is yet to be prepared. Unlike earlier studies, this paper has considered accounts and agent outlets dealing with mobile money as well as transactions carried out through mobile and internet banking (Banna and Alam, 2021b; Banna and Alam, 2021c) to create a DFI index.

As the demand-side (usage of digital finance) factors, the study has considered both the number of transations and accounts dealing with mobile and internet banking per 1,000 adults (during the reference year). Agent outlests per 100,000 adults and per 1,000 $\mathrm{km}^{2}$ dealing with mobile money have been taken into account as the supply-side (access to digital finance) factors. It has endorsed mobile money, a digitalized platform through which users can receive, send, and pay their desired amount instantly by using their smart phone (Subramaniam, 2020). Such types of mobile money (digital money) services widen the outreach by improving the access of the deprived and underprivileged community to financial services. However, we could not achieve this since the poor and deprived community residing in remote areas are disinclined towards formal banking and financial services due to their incapacity to arrange the certain/minimum amount required for opening an account in formal banking. Furthermore, the lockdown and social distancing policies due to the COVID-19 generate a considerable prospect for the Islamic banking sector to enhance its mobile and internet banking services to move towards digital finance. As a result, mobile and internet banking increases the number of the banked population and enhances banking stability by minimizing service costs and maximizing profit and efficiency of the bank. 
Since the variables taken to construct an index of DFI are greatly correlated, we have developed a comprehensive DFI index with the help of the Principal Components Analysis $\left(\mathrm{PCA}^{4}\right)$ so that we can determine the common variation among the proxies. This index will sufficiently deal with the over-parameterization and the setbacks of multicollinearity as a single measure of DFI (Ahamed and Mallick, 2019). Using the PCA model, we have initially measured the demand-side (usage) and the supply-side (access) indexes individually, after their combination, to create a comprehensive DFI index. Then, all these three indices (DFI-access, DFI-usage, and overall DFI indices) have been normalized with the help of the minimummaximum normalization technique so that we can avoid a negative value with a scale of $0-1$, in which zero refers to digital financial exclusion, and one represents digital financial inclusion. In addition, this paper has also considered an alternative DFI proxy. For this, it has used digital payments either made or received in the past year (\% age $15+)$ extracted from the database of the World Bank Global Findex.

\subsubsection{Bank-related and Macroeconomic factors}

Following the previous studies (e.g., Fang et al., 2014; Banna and Alam, 2021c), the study considers SIZE (bank size - logarithm of total assets), LR (loan ratio), RD (revenue diversification), CAP (capitalisation), MQ (management quality), HHI (Herfindahl-Hirschman Index), LI (Lerner Index), INFL (inflation), GDPG (GDP growth rate), and GG (good governance) to control bank-related and macroeconomic factors. The good governance index has been formed with a standardized approach taken from Kaufmann et al. (2010), that is consisted of $\operatorname{six}^{5}$ governance indicators.

\subsubsection{Estimation Techniques}

\footnotetext{
${ }^{4}$ The PCA results have not been provided here, but they are available upon request.

${ }^{5}$ Government effectiveness, control of corruption, voice and accountability, regulatory quality, political stability and absence of violence/terrorism, and the rule of law.
} 
The study has used the following baseline regression analysis to examine the impact of Digital financial inclusion on Islamic banking stability:

$$
Y_{i j t}=\alpha+\beta D F I_{j t}+\varnothing B_{i j t}+\omega M_{j t}+\varepsilon_{i j t}
$$

Where, $Y_{i j t}$ refers to the proxies of the dependent variable [ln (Z-score) and In (Sharp ratio)bank stability] $i$ of country $j$ in year $t$; $D F I_{j t}$ refers to the index of Digital financial inclusion of a country $j$ in year $t$; $B_{i j t}$ denotes a bank's bank-related factors $i$ of country $j$ in year $t$ (such as SIZE, $L R, R D, M Q, C A P$, and $H H I) ; M_{j t}$ signifies a country's macroeconomic factors $j$ in year $t$ (such as LI, INFL, GDPG, and GG); the characters $\beta, \emptyset$, and $\omega$ are the variables' coefficients; and error term is represented by $\varepsilon_{i j t}$.

Following Banna and Alam (2021c) and Alfadli and Rjoub (2019), this study considers the PCSE method of Beck and Katz (1995) to find the baseline relationship between DFI and the stability of the Islamic banks. After that, to minimize the potential endogeneity issues and the unobserved time-invariant bank-related heterogeneity effect, this study employs the TwoStage Panel Least Squares-Instrumental Variables (2SLS-IV) and Blundell and Bond's (1998) the dynamic two-step system GMM panel regression methods following Kim et al. (2020) and Ahamed and Mallick (2019) as a robustness test.

\section{Results and Analysis}

This portion of the study illustrates the descriptive statistics, the major findings as well as the description of the nexus of DFI-Islamic banking stability amidst the COVID-19 pandemic and the various robustness tests of the results.

\subsection{Descriptive Statistics}

Table II explicates the descriptive statistics of the variables that have been used in this study. It is noticed that the sample Islamic banks, on an average, have a $\ln (\mathrm{Z}$-score) value of 3.85 
with 1.24 standard deviation (SD) and a $\ln$ (sharp ratio) value of 1.51 with $1.36 \mathrm{SD}$, which suggest that to obliterate equity of the sample Islamic banks, ROAA would have to drop by an average 3.85 times of their SD and ROAE would have to fall by 1.24 times (on average) of their SD. In addition, the mean and SD of bank size of the Islamic banks are 7.3 and 1.97 , respectively, indicating a relatively high yearly variation among the sample banks.

Moreover, The DFI components suggest that the existing banks or other financial institutions in this region avail people with access to financial services through mobile agents, mobile money accounts, other digital financial services, etc. Apart from that, on an average, Bangladesh has the highest score in terms of DFI-access index as well as overall DFI index among the sample countries as shown in Figure 1. At the same time, for the DFI-usage index, Indonesia and Malaysia are better positioned. However, Sudan has the lowest scores in all indices. Thus, the mix-scoring position of the sample countries suggests that there is room for improvement in their DFI indices score.

\section{PLEASE INSERT TABLE II HERE \\ PLEASE INSERT FIGURE 1 HERE}

\subsection{DFI and Islamic Banking Stability}

In this section, the key findings and the analysis of the study have been provided. We have relied on the PCSE regression model to examine the relationship between Islamic banking stability and DFI (Table III). The PCSE reduces the cross-sectional dependency and the prevailing sequential correlation problems as well as captures the likelihood of endogeneity among the dependent and independent factors in a particular model using a suitable instrument (Alfadli and Rjoub, 2019).

On the basis of two dimensions, the analysis of this study has been carried out: Firstly, the two proxies such as $\ln ($ sharp ratio) (Model 1-3) and $\ln (\mathrm{Z}$-score) (Model 4-6) of Islamic 
banking stability, and secondly, the three DFI indices, viz. DFI-access index (Model 1 \& 4), DFI-usage index (Model $2 \& 5$ ), and Overall DFI index (3 \& 6) as depicted in Table III. The study has also controlled variables related to banks such as SIZE, LR, MQ, CAP, RD, HHI, LI; macroeconomic variables such as INFL, GG, and GDPG; and the country effect.

\section{PLEASE INSERT TABLE III HERE}

The results (in Table III) confirm a significant positive association between overall DFI and Islamic banking stability in both measures (Z-score and Sharp ratio). This implies that more DFI ensures better Islamic banking stability (a high Z-score and Sharp ratio indicate greater stability). For example, the coefficient of the overall DFI index on Islamic banking stability denotes that an increase of one SD in the overall DFI index (SD- 0.22) corresponds to an increase in the Sharp ratio of $12.54 \%(0.22 \times 0.57)$ and a rise in the Z-score of $7.04 \%$ $(0.22 \times 0.32)$. This affirms the statistical significance and economic importance of DFI since it accelerates the safety and security of each Islamic bank in the sample countries. Such findings of the study are akin to previous studies of (e.g., Banna et al., 2020b; Banna, 2020; Ahamed and Mallick, 2019; Morgan and Pontines, 2018), who found that any financial organisation backed by higher level of DFI and FI ascents to improve banking stability. Moreover, proper execution of DFI minimises banks' extreme risk-taking tendency which might bring instability.

Besides, it implies that any banking industry with inclusive DFS may help the bank to minimize liquidity crisis through the generation of sufficient cliental deposits at a low price, which ultimately reduces pro-cyclicality risk. Apart from that, the expansion of digital finance services or products accessible through smart digital devices (e.g., smart phone, laptop, tablet, etc.) may minimize in-person dealings while maintaining the financial transactions/activities even in the face of crisis, which eventually improves the banking stability. Thus, restrictions on people's movement in response to the COVID-19 provide an opportunity for the Islamic banking industry to rapidly launch DFS in full swing. Although the proper execution of DFI 
has drawn the attention of the policymakers and financial analysts long ${ }^{6}$ before the emergence of this uncertainty, this Covid-19 has further highlighted the need to explore the role of DFI in cushioning the effect of the crisis on the financial institution, thus accelerating the rapid implementation of DFI.

The overall DFI and DFI-access indices have a strong association with Islamic banking stability proxies, contrary to the usage of DFI, which exhibits a negative and insignificant relationship with bank stability. This suggests that Islamic banks as well as other financial organisations in the region have provided adequate access to finance, albeit the people's aversion towards it. It could be explicated by the fact that people of this region lack digital financial literacy, BigTech financial institutions provide better financial facilities, and mobile money transaction is costlier than traditional banking services (Banna and Alam, 2021b; Morgan et al., 2019). Besides, slow and interrupted internet facilities, data privacy issues, and cyber insecurity (Adeoti, 2011) may also discourage them from a proper use of digital financial services. The findings agree with that of Banna and Alam (2021b) on conventional banks of emerging Asian countries.

DFI seems to be an instrument to aid regulators dealing with financial and monetary affairs minimise inflation in both developing and poor countries by imposing restrictions on the amount of cash in circulation. Moreover, to bring welfare for business sectors and for individuals, DFI plays a vivid role as people can enjoy their financial transaction instantly and very easily without any physical movement that saves their time, money and energy as well (CGAP., 2015). Furthermore, in times of any crisis like this COVID-19, DFI could assist governments' provision of emergency financial support to the unbanked population and to those in the informal job sector. In addition, Islamic banks with inclusive DFS are likely to ensure

\footnotetext{
${ }^{6}$ In 2018, the Bali fintech agenda was launched to intensify the proper execution of DFS/FinTech based financial inclusion at the Annual Meeting of IMF and World bank.
} 
higher level of financial stability in the time of economic recession like this Covid-19. Apart from that, SIZE, GG, MQ, and $\mathrm{HHI}$ are also considered as influential determinants for ensuring Islamic banking stability.

\subsection{Robustness Checks}

This section of the study elucidates the robustness of the findings by using different methods, splitting the sample size, and using alternative DFI and bank stability proxies. First, this study utilized the 2SLS-IV model with valid instruments to control possible endogeneity issues. Second, to lessen the unobserved time-invariant bank-specific heterogeneity effect, the twostep system GMM technique has been deployed. Subsequently, we split our sample size based on the bank size. Finally, the study considered an alternative proxy for DFI and bank stability.

\subsubsection{Robustness: Two-Stage Panel Least Squares--Instrumental Variables (2SLS-IV) Regression and Two-Step System GMM Dynamic Panel Regression}

Although reverse causality (endogeneity), in any banking study, is a usual identification issue (Ahamed and Mallick, 2019), it is of less concern in our research, which examines the impact of DFI (a country-level indicator) on Islamic banking stability (bank-level indicator). Yet, the study has carried out a 2SLS-IV analysis to check the robustness of its results that is in line with Kim et al. (2020).

In order to select instrumental variables (IVs) for addressing any potential endogeneity issue, this study has looked into the recently published empirical studies dealing with FI and banking stability. Following Ahamed and Mallick (2019) and Banna and Alam (2021b), the study has used the number of handphone subscriptions per 100 people as an instrumental variable used for the 2SLS-IV since this is used as an IV in other countries of the same region. We argue that the banking operational costs and various types of deficiencies (e.g., physical, financial, and infrastructural) could be minimised through developing an easy communication 
channel (Beck et al., 2007) and the mass use of the handphone for financial transactions (Allen et al., 2014). Hence, countries with a larger number of smartphone users help reduce the number of the unbanked population, which might not influence bank stability directly but might impact DFI.

Moreover, the study has also considered percentage of adults who take loans from their family members and friends as an instrumental variable. We find that in most of the developing countries, friends and family are the key sources of taking loans (Demirguc-Kunt and Klapper, 2012). In terms of taking loans from formal financial institutions, only $9 \%$ of the adults were reported, whereas $29 \%$ were reported taking loans from their family members and friends. Such a greater number of adults taking loans from their family members and friends might have impact on DFI but not on bank stability (Ahamed and Mallick, 2019).

\section{PLEASE INSERT TABLE IV HERE}

The 2SLS-IV regression model agrees with the above analysis result, as it shows that DFI and Islamic banking stability has a stronger association that is indicated by a higher coefficient as depicted in Table IV. Hence, the robustness of the PCSE regression results is confirmed with the findings which suggest that overall and access DFI indices have a significant positive impact on Islamic banking stability as these help minimise banks' default risk during a crisis period. This suggests that the proper implementation of DFI in Islamic banks will promote their financial stability during the COVID-19 pandemic.

Besides, this study has also considered two-step system GMM dynamic panel regression ${ }^{7}$ to assess the dynamic relationship between DFI and Islamic banking stability. After taking time-series variation into account, the results remain same that confirms the robustness showing a positive association between DFI index and Islamic banking stability.

\subsubsection{Robustness: Big Banks vs. Medium and Small Banks}

\footnotetext{
${ }^{7}$ The results are available upon reasonable request.
} 
Based on the bank size, data have been further subdivided into two. Like Azmi et al. (2019), we have considered banks with total assets more than USD I billion as big banks, otherwise, medium and small banks. Thus, after splitting the sample of the total 65 banks, 37 and 28 are considered big and medium (small)-sized.

\section{PLEASE INSERT TABLE V HERE}

Table V displays the estimation results of the split sample. The findings suggest that all forms of DFI indices of big banks play a positive role in ensuring Islamic banking stability. A similar relationship was observed for medium and small banks, except that it is not significant. This result suggests that SIZE has an important positive relationship with Islamic banking stability and indicates the inadequacy of small and medium Islamic banks in adopting technology-based financial services.

\subsubsection{Robustness: Alternative DFI and Bank Stability Proxies}

Similar to Banna (2020), this study has taken an alternative proxy of DFI (in Panel A) which is what percentage of adults, in the past year, used digital payment method for their financial transactions (MORDIGPAY). This proxy empirically shows the adoption of digital financial transactions among the adults in the country. It also indicates the contribution of DFS to the country's overall GDP. The study also employed Non-Performing Loans (NPLs) (in Panel B) as an alternative proxy for bank stability (the higher the NPLs, the lower the bank stability).

\section{PLEASE INSERT TABLE VI HERE}

Using alternative proxies (in Table VI), the results affirm the robustness of the former results. Hence, it is very obvious that Islamic banks will enjoy greater financial stability with an inclusive digitalized financial sector. In this regard, Islamic banks with proper and inclusive DFI in the sample countries are likely to augment their stability amidst the COVID-19 pandemic. Furthermore, DFI can facilitate the government's emergency response to vulnerable groups during a crisis period. Hence, expansion of DFS in the sample countries remains an 
effective means by which the Islamic banking sector can maintain its stability and subsequently ensures financial and economic resilience even at the time of any uncertain crisis.

\section{Conclusion}

This study has examined the association between DFI and Islamic banking stability. To see this association, the study has considered 65 Islamic banks from 6 countries as samples from the year 2011 to 2020 . The results of the study denote that higher level of DFI promotes Islamic banking stability through minimising banks' default risk. Consequently, an integrated DFI in the Islamic banking sector can ensure sustainable economic growth during crisis periods like the COVID-19 pandemic. Further investigations revealed that the results of this study are robust.

The government and policymakers can see DFI as a developmental instrument that offers a ground-breaking and long-term development for Islamic banks even in times of any recession like the Covid-19 pandemic. Based on our findings, the following specific policies are recommended.

First, our results showed that small and medium Islamic banks' stability exhibit an insignificant relationship with DFI. Therefore, medium and small-sized banks need to widen their service points and agent networks. They should upgrade their current digital finance products and services reckoning the need of the average people through the inclusion of machine learning and artificial intelligence (AI) to attract more clients to their services/products. Islamic banks should also introduce remote account opening services through electronic devices, as many people are afraid of going to agent outlets or bank branches due to the COVID-19 pandemic.

Second, the insignificant nexus between the usage of DFI and bank stability implies that banks should provide mass community with necessary digital financial literacy by 
arranging various types of workshops, seminars, campaigns, and so on. Third, the regulatory body should ensure that clients' electronic devices have an uninterrupted internet connection and are supported with the latest technology. Fourth, to prevent card cloning, Islamic banks in the sample countries should upgrade their databases and employ innovative and secured money withdrawal method such as the use of QR code, which is prevalent in countries like Singapore, Turkey, and so on. Finally, there should be a strong, independent, proficient, and unbiased regulatory body that will supervise all the activities of DFI and adopt innovative and timetested policies to ensure its effective and efficient implementation.

As expected, this study is not bereft of some limitations, as it fails to consider all Islamic banks-operating countries in its analysis due to the unavailability of DFI data, thus providing scope for future studies.

\section{References}

Adeoti, J. O. 2011, "Automated teller machine (ATM) frauds in Nigeria: The way out", Journal of Social Sciences, Vol. 27 No. 1, pp.53-58.

Ahamed, M. M. \& Mallick, S. K. 2019, "Is financial inclusion good for bank stability? International evidence", Journal of Economic Behavior \& Organization, Vol. 157 No. C, pp.403-427.

Ahmed, A. 2010, "Global financial crisis: an Islamic finance perspective", International Journal of Islamic and Middle Eastern Finance and Management, Vol. 3 No. 4, pp.306-320. doi:https://doi.org/10.1108/17538391011093252

Ahmed, H., Mohieldin, M., Verbeek, J. \& Aboulmagd, F. 2015, "On the sustainable development goals and the role of Islamic finance", The World Bank.

Alfadli, A. \& Rjoub, H. 2019, "The impacts of bank-specific, industry-specific and macroeconomic variables on commercial bank financial performance: evidence from the Gulf cooperation council countries", Applied Economics Letters, Vol. No. pp.1-5.

Allen, F., Carletti, E., Cull, R., Qian, J. Q., Senbet, L. \& Valenzuela, P. 2014, "The African financial development and financial inclusion gaps", Journal of African economies, Vol. 23 No. 5, pp.614-642. 
Arner, D. W., Buckley, R. P. \& Zetzsche, D. A. 2018, "Fintech for Financial Inclusion: A Framework for Digital Financial Transformation-A Report to the Alliance for Financial Inclusion (AFI)", Vol. No.,

Atkeson, A. 2020. "What will be the economic impact of covid-19 in the us? rough estimates of disease scenarios". National Bureau of Economic Research.

Azmi, W., Ali, M., Arshad, S. \& Rizvi, S. A. R. 2019, "Intricacies of competition, stability, and diversification: Evidence from dual banking economies", Economic Modelling, Vol. 83 No. pp.111-126. doi:https://doi.org/10.1016/j.econmod.2019.02.002

Baldwin, R. \& di Mauro, B. W. 2020, "Mitigating the COVID economic crisis: Act fast and do whatever it takes", VoxEU. org eBook, Vol. No.,

Banna, H. 2020, "The role of digital financial inclusion on promoting sustainable economic growth through banking stability: Evidence from Bangladesh", Development Review, Vol. 29 No. 2020, pp.19-36.

Banna, H. \& Alam, M. R. 2020, "ISLAMIC BANKING EFFICIENCY AND INCLUSIVE SUSTAINABLE GROWTH: THE ROLE OF FINANCIAL INCLUSION", Journal of Islamic Monetary Economics and Finance, Vol. 6 No. 1.

Banna, H. \& Alam, M. R. 2021a, "Impact of digital financial inclusion on ASEAN banking stability: Implications for the post-Covid-19 era", Studies in Economics and Finance, Vol. 38. No.2, pp.504-523. doi:10.1108/SEF-09-2020-0388

Banna, H. \& Alam, M. R. 2021b, "Is Digital Financial Inclusion Good for Bank Stability and Sustainable Economic Development? Evidence from Emerging Asia", ADBI Working Paper, Vol. No. 1242, pp.1-21. https://www.adb.org/publications/digital-financialinclusion-good-bank-stability-sustainable- economic-development-asia

Banna, H. \& Alam, M. R. 2021c, "Does Digital Financial Inclusion Matter for Bank Risktaking? Evidence from Dual banking System", Journal of Islamic Monetary Economics and Finance, Vol. 7. No.2, pp.401-430. doi: 10.21098/jimf.v7i2.1320

Banna, H., Alam, M. R., Ahmad, R. \& Sari, N. M. 2020a, "Does financial inclusion drive the Islamic banking efficiency? A post-financial crisis analysis", The Singapore Economic Review, Vol. No. doi:10.1142/s0217590819420050

Banna, H., Hassan, M. K. \& Alam, M. R. 2020b, "Digital Financial Inclusion, Islamic Banking Stability and Sustainable Economic Growth”, In: Saraç, M. \& Hassan, M. K. (eds.) Islamic Perspective for Sustainable Financial System. Istanbul University Press, Istanbul, pp.131-152. doi: 10.26650/B/SS10.2020.017.07

Beck, N. \& Katz, J. N. 1995, "What to do (and not to do) with time-series cross-section data", American political science review, Vol. 89 No. 3, pp.634-647.

Beck, T., Demirguc-Kunt, A. \& Martínez-Pería, M. S. 2007, "Reaching out: Access to and use of banking services across countries", Journal of financial economics, Vol. 85 No. 1, pp.234-266.

Beck, T., Senbet, L. \& Simbanegavi, W. 2014, "Financial inclusion and innovation in Africa: An overview", Journal of African Economies, Vol. 24 No. suppl_1, pp.i3-i11.

Blundell, R. \& Bond, S. 1998, "Initial conditions and moment restrictions in dynamic panel data models", Journal of econometrics, Vol. 87 No. 1, pp.115-143.

CGAP. 2015. "What is Digital Financial Inclusion and Why Does it Matter?".

Demirguc-Kunt, A. \& Klapper, L. 2012, "Measuring financial inclusion: The global findex database", The World Bank.

Ellis, M. 2020. How Digital Banking Saved the Day During the COVID-19 Pandemic. Available from: https://thefinancialbrand.com/96448/covid-19-coronavirus-howdigital-banking-saved-the-day-during-the-covid-19-pandemic/. 
Fang, Y., Hasan, I. \& Marton, K. 2014, "Institutional development and bank stability: Evidence from transition countries", Journal of Banking \& Finance, Vol. 39 No. pp.160-176.

Gabor, D. \& Brooks, S. 2017, "The digital revolution in financial inclusion: international development in the fintech era", New Political Economy, Vol. 22 No. 4, pp.423-436.

Group, W. B. 2013. "Global financial development report 2014: Financial inclusion". World Bank Publications: World Bank Publications.

Hasan, R., Hassan, M. K. \& Aliyu, S. 2020, "Fintech and Islamic Finance: Literature Review and Research Agenda", International Journal of Islamic Economics and Finance (IJIEF), Vol. 3 No. 1, pp.75-94.

Hassan, M. \& Dridi, J. 2010. "The Effects of the Global Financial Crisis on Islamic and Conventional Banks: A comparative Study". IMF Working Paper WP/10201: IMF Working Paper WP/10201.

Hassan, M. K. \& Bashir, A.-H. M. "Determinants of Islamic banking profitability", 10th ERF annual conference, Morocco, 2003. pp.2-31.

Hassan, M. K., Hossain, S. \& Unsal, O. 2018, "RELIGIOUS PREFERENCE AND FINANCIAL INCLUSION: THE CASE FOR ISLAMIC FINANCE", Management of Islamic Finance: Principle, Practice, and Performance, Vol. No. pp.93.

Imam, P. \& Kpodar, K. 2013, "Islamic banking: how has it expanded?", Emerging Markets Finance and Trade, Vol. 49 No. 6, pp.112-137.

Imam, P. \& Kpodar, K. 2016, "Islamic banking: Good for growth?", Economic Modelling, Vol. 59 No. pp.387-401.

Kaufmann, D., Kraay, A. \& Mastruzzi, M. 2010, "The worldwide governance indicators: A summary of methodology", Data and Analytical Issues, World Bank Policy Research Working Paper, Vol. 5430 No.,

Kayed, R. N. \& Hassan, M. K. 2011, "The global financial crisis and Islamic finance", Thunderbird International Business Review, Vol. 53 No. 5, pp.551-564.

Kim, H., Batten, J. A. \& Ryu, D. 2020, "Financial crisis, bank diversification, and financial stability: OECD countries", International Review of Economics \& Finance, Vol. 65 No. pp.94-104.

Kim, D-W, Yu, J-S, and Hassan, M . K. 2020, "The Influence of Religion and Social inequality on Financial Inclusion", Singapore Economic Review, Vol. 65 No.1, pp.193-216.

Klapper, L., Miller, M. \& Hess, J. 2019. "Leveraging Digital Financial Solutions to Promote Formal Business Participation". World Bank.

Knaack, P. \& Gruin, J. 2020, "From shadow banking to digital financial inclusion: China's rise and the politics of epistemic contestation within the financial stability board", Review of International Political Economy, Vol. No. pp.1-25. doi:10.1080/09692290.2020.1772849

Koh, F., Phoon, K. F. \& Ha, C. D. 2018, "Digital financial inclusion in South East Asia", Handbook of Blockchain, Digital Finance, and Inclusion, Volume 2. Elsevier, pp.387-403.

Mani, M. 2016, "Financial Inclusion in South Asia—Relative Standing, Challenges and Initiatives", South Asian Survey, Vol. 23 No. 2, pp.158-179.

Manyika, J., Lund, S., Singer, M., White, O. \& Berry, C. 2016, "Digital finance for all: Powering inclusive growth in emerging economies", McKinsey Global Institute, Vol. No.,

Mirakhor, A. 2008, "Lesson of the recent crisis for Islamic finance", IIUM Journal of Economics and Management, Vol. 16 No. 2, pp.132-138. 
Morgan, P. J., Huang, B. \& Trinh, L. Q. 2019. The need to promote digital financial literacy for the digital age. IN THE DIGITAL AGE [Online]. Available from: https://t20japan.org/policy-brief-need-promote-digital-financial-literacy/.

Morgan, P. J. \& Pontines, V. 2018, "Financial stability and financial inclusion: The case of SME lending", The Singapore Economic Review, Vol. 63 No. 01, pp.111-124.

Moufakkir, M. \& Mohammed, Q. 2020, "The Nexus Between FinTech Adoption and Financial Inclusion", Impact of Financial Technology (FinTech) on Islamic Finance and Financial Stability. IGI Global, pp.193-209.

Naceur, S. B., Barajas, A. \& Massara, A. 2017, "Can Islamic banking increase financial inclusion?", Handbook of empirical research on Islam and economic life. Edward Elgar Publishing.

Naumenkova, S., Mishchenko, S. \& Dorofeiev, D. 2019, "Digital financial inclusion: Evidence from Ukraine", Investment Management and Financial Innovations, Vol. 16 No. 3, pp.194-205.

Neaime, S. \& Gaysset, I. 2018, "Financial inclusion and stability in MENA: Evidence from poverty and inequality", Finance Research Letters, Vol. 24 No. pp.230-237.

Ozili, P. K. 2018, "Impact of digital finance on financial inclusion and stability", Borsa Istanbul Review, Vol. 18 No. 4, pp.329-340.

Pénicaud, C. \& Katakam, A. 2019, "State of the industry 2013: Mobile financial services for the unbanked", Gates Open Res, Vol. 3 No.,

Rashid, A., Yousaf, S. \& Khaleequzzaman, M. 2017, "Does Islamic banking really strengthen financial stability? Empirical evidence from Pakistan", International Journal of Islamic and Middle Eastern Finance and Management, Vol. 10 No. 2, pp.130-148. doi:https://doi.org/10.1108/IMEFM-11-2015-0137

Salami, M. A., Sarea, A. M. \& Hassan, M. K. 2020, "Financial inclusion and risk exposure among different income groups: The impact of COVID-19 pandemic", In: Hassan, M. K., Muneeza, A. \& Sarea, A. M. (eds.) Impact of COVID-19 and Islamic Social Finance. Routledge, Singapore, pp.44-60.

Senou, M. M., Ouattara, W. \& Acclassato Houensou, D. 2019, "Financial inclusion dynamics in WAEMU: Was digital technology the missing piece?", Cogent Economics \& Finance, Vol. 7 No. 1, pp.1665432.

Siddik, M. N. A. \& Kabiraj, S. 2020, "Digital Finance for Financial Inclusion and Inclusive Growth", Digital Transformation in Business and Society. Springer, pp.155-168.

Subramaniam, P. 2020, "Banking: Digital initiatives aimed at financial inclusion". The Edge Malaysia.

Thaker, H. M. T., Sakaran, K. C., Nanairan, N. M., Thaker, M. A. M. T. \& Hussain, H. I. 2020, "Drivers of loyalty among non-Muslims towards Islamic banking in Malaysia", International Journal of Islamic and Middle Eastern Finance and Management, Vol. 13 No. 2, pp.281-302. doi: https://doi.org/10.1108/IMEFM-07-2018-0211

Van, L. T.-H., Nguyen, N. T. \& Vo, D. H. 2020, "Financial Inclusion and Stability in the Asian Region Using Bank-Level Data", Borsa Istanbul Review, Vol. No.,

Yin, H. 2019, "Bank globalization and financial stability: International evidence", Research in International Business and Finance, Vol. 49 No. pp.207-224. doi:https://doi.org/10.1016/j.ribaf.2019.03.009

Yu, J-S, Kim, D-W, and Hassan, M . K. 2019, " Financial Inclusion and Economic Growth in OIC Countries ", Research in International Business and Finance, Vol. 43, pp.1-14. doi: https://doi.org/10.1016/j.ribaf.2017.07.178 
$\underline{\text { Figure }}$

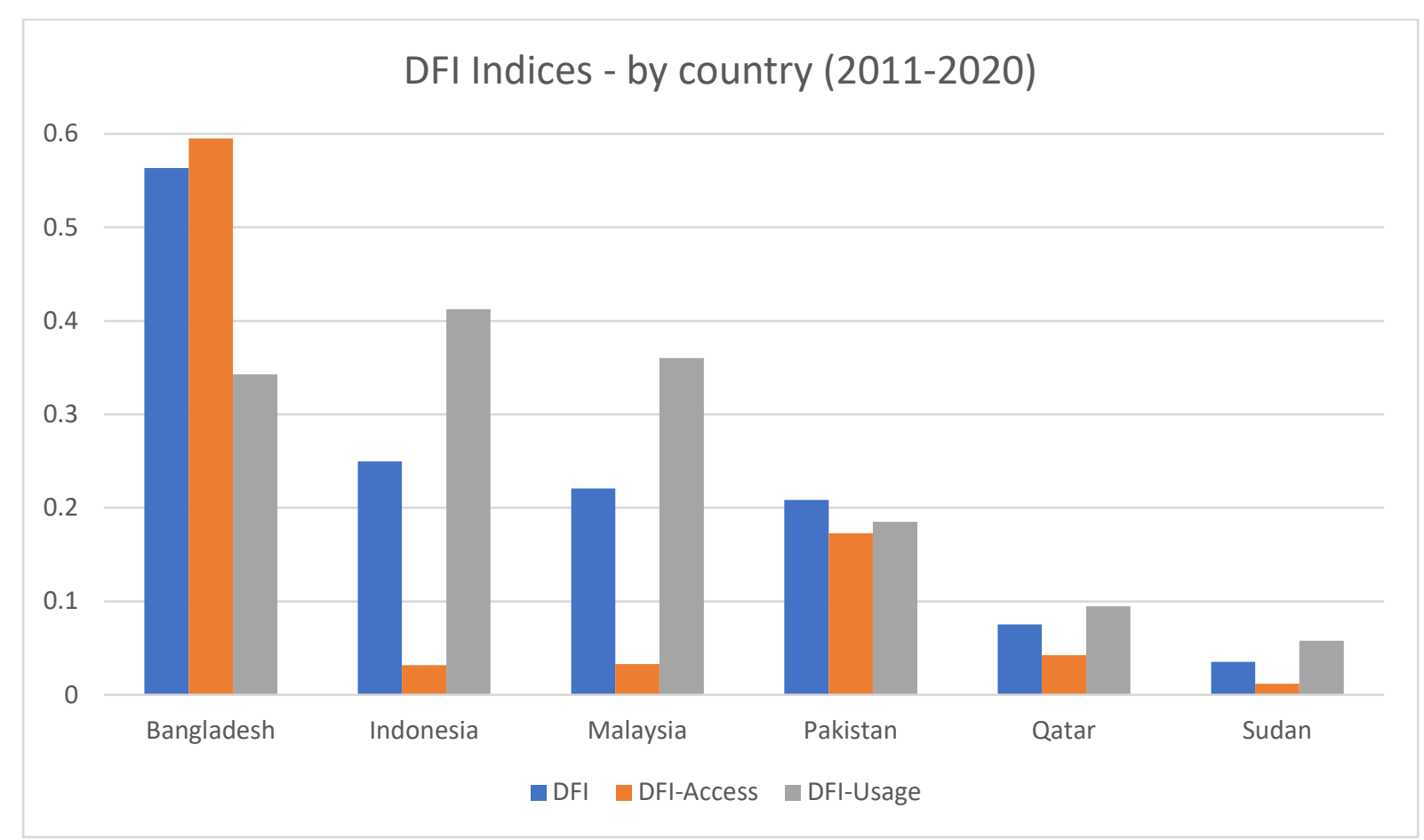

Figure 1: DFI indices (Overall, Access, Usage) by country over the period of 2011-2020. Source: Author's calculation using principle component analysis (PCA) based on the financial access survey (FAS) of International Monetary Fund (IMF)'s data. 


\section{Tables}

Table I: The sample selection process, list of countries and number of banks

Panel A: Sample Section Process

\begin{tabular}{lc}
\hline Step & Number of banks \\
\hline All Islamic banks (Algeria, Bangladesh, Bahrain, Brunei Darussalam, Cyprus, Egypt, & 225 \\
Germany, Guinea, Indonesia, Iran, Jordan, Kenya, Kuwait, Lebanon, Libya, Malaysia, & \\
Maldives, Mauritania, Nigeria, Oman, Philippines, Pakistan, Palestine, Qatar, Saudi & \\
Arabia, Sri Lanka, Singapore, South Africa, Syria, Sudan, Tanzania, Thailand, Turkey, & \\
Tunisia, United Kingdom, United Arab Emirates, and Yemen) & \\
Excluded countries (Algeria, Bahrain, Brunei Darussalam, Cyprus, Egypt, Germany, & $(159)$ \\
Guinea, Iran, Jordan, Kenya, Kuwait, Lebanon, Libya, Maldives, Mauritania, Nigeria, & \\
Oman, Philippines, Palestine, Saudi Arabia, Sri Lanka, Singapore, South Africa, Syria, & \\
Tanzania, Thailand, Turkey, Tunisia, United Kingdom, United Arab Emirates, and & \\
Yemen)- due to DFI data unavailability, single bank operation, missing data of three & \\
years consecutively & \\
Included countries (Bangladesh, Indonesia, Malaysia, Pakistan, Qatar and Sudan) & 66 \\
Excluded one bank due to mis-specialisation & $(1)$ \\
\hline Final Sample & $\mathbf{6 5}$ \\
\multicolumn{1}{c}{ Panel B: Sample by country } & \\
\hline Country & Number of Banks \\
\hline Bangladesh & $($ Proportion) \\
\hline Indonesia & $8(12 \%)$ \\
Malaysia & $11(17 \%)$ \\
Pakistan & $17(26 \%)$ \\
Qatar & $9(14 \%)$ \\
Sudan & $5(8 \%)$ \\
\hline Total & $15(23 \%)$ \\
\hline
\end{tabular}

This table reports the proportion of the sample size and the sample selection process used in this study. 
Table II: Descriptive statistics

\begin{tabular}{|c|c|c|c|c|c|}
\hline Variable & Obs & Mean & Std. Dev. & Min & Max \\
\hline \multicolumn{6}{|l|}{ Banking stability } \\
\hline $\begin{array}{l}\mathrm{Ln}(\mathrm{Z} \text {-score) using return on average assets (ROAA) } \\
\text { (LZS) }\end{array}$ & 450 & 3.846 & 1.237 & -2.412 & 7.854 \\
\hline $\begin{array}{l}\mathrm{Ln}(\text { Sharp ratio) using return on average equity } \\
\text { (ROAE) }\end{array}$ & 428 & 1.507 & 1.357 & -4.588 & 6.064 \\
\hline Non-performing loans ratio (NPLs) & 305 & 6.50 & 15.034 & 0.002 & 81.997 \\
\hline \multicolumn{6}{|l|}{ Digital Financial Inclusion proxies and indices } \\
\hline $\begin{array}{l}\text { Number of mobile money agent outlets per } 1,000 \\
\mathrm{~km}^{2}\end{array}$ & 527 & 606.218 & 1608.621 & 0.4 & 6869.77 \\
\hline $\begin{array}{l}\text { Number of mobile money agent outlets per 100k } \\
\text { adults }\end{array}$ & 527 & 121.796 & 182.163 & 3.682 & 768.054 \\
\hline Number of mobile money accounts per 1,000 adults & 527 & 146.023 & 193.613 & 0.393 & 855.869 \\
\hline $\begin{array}{l}\text { Number of mobile and internet money transactions } \\
\text { (during the reference year) per } 1,000 \text { adults }\end{array}$ & 527 & 54629.44 & 104000 & 0 & 400000 \\
\hline $\begin{array}{l}\text { Comprehensive digital financial inclusion index } \\
\text { using PCA (DFI - Overall) }\end{array}$ & 527 & 0.221 & 0.235 & 0 & 1 \\
\hline $\begin{array}{l}\text { Digital financial inclusion (access - supply side) } \\
\text { index using PCA (DFI - Access) }\end{array}$ & 527 & 0.121 & 0.233 & 0 & 1 \\
\hline $\begin{array}{l}\text { Digital financial inclusion (usage - demand side) } \\
\text { index using PCA (DFI - Usage) }\end{array}$ & 527 & 0.265 & 0.257 & 0 & 1 \\
\hline $\begin{array}{l}\text { Made or received digital payments in the past year } \\
(\% \text { age } 15+) \text { (MORDIGPAY) } \\
\text { Bank-specific variables }\end{array}$ & 485 & 0.322 & 0.224 & 0.074 & 0.718 \\
\hline Bank size (SIZE) & 527 & 7.289 & 1.974 & 0.322 & 11.001 \\
\hline Loan ratio (LR) & 527 & 0.633 & 0.195 & 0.007 & 1.129 \\
\hline Management quality (MQ) & 527 & 0.804 & 0.205 & 0.041 & 0.994 \\
\hline Capitalisation (CAP) & 527 & 0.124 & 0.206 & -1.207 & 0.983 \\
\hline Revenue diversification (RD) & 522 & 3.817 & 1.045 & -2.919 & 5.783 \\
\hline Herfindahl-Hirschman index (HHI) & 527 & 0.214 & 0.088 & 0.113 & 0.627 \\
\hline \multicolumn{6}{|l|}{$\underline{\text { Macroeconomic variables }}$} \\
\hline Lerner Index (LI) & 527 & 0.293 & 0.135 & 0.003 & 0.604 \\
\hline Gross domestic product growth rate (GDPG) & 527 & 4.685 & 2.131 & -2.556 & 13.375 \\
\hline Inflation (CPI) (INFL) & 527 & 9.571 & 12.891 & -0.667 & 63.293 \\
\hline Good governance index (GG) & 527 & 0.528 & 0.33 & 0 & 1 \\
\hline \multicolumn{6}{|l|}{ Instrumental variables } \\
\hline $\begin{array}{l}\text { Mobile cellular subscriptions (per } 100 \text { people) - } \\
\text { Mobile Share (MBSHARE) }\end{array}$ & 527 & 0.934 & 0.033 & 0.883 & 0.987 \\
\hline $\begin{array}{l}\text { Borrowed from family or friends (\% age } 15+\text { ) } \\
\text { (BRFNF) }\end{array}$ & 527 & .311 & 0.089 & 0.105 & 0.474 \\
\hline
\end{tabular}

This table provides the definition of all variables used in this study and their descriptive statistics. 


\begin{tabular}{|c|c|c|c|c|c|c|}
\hline & \multicolumn{3}{|c|}{ Ln(Sharp ratio) } & \multicolumn{3}{|c|}{ Ln(Z-score) } \\
\hline & (1) & (2) & (3) & (4) & (5) & (6) \\
\hline & DFI-Access & $\begin{array}{l}\text { DFI- } \\
\text { Usage }\end{array}$ & $\begin{array}{c}\text { DFI- } \\
\text { Overall }\end{array}$ & DFI-Access & $\begin{array}{l}\text { DFI- } \\
\text { Usage }\end{array}$ & $\begin{array}{c}\text { DFI- } \\
\text { Overall }\end{array}$ \\
\hline DFI & $\begin{array}{c}1.181^{* * *} \\
(0.343)\end{array}$ & $\begin{array}{l}-0.187 \\
(0.326)\end{array}$ & $\begin{array}{c}0.567 * * * \\
(0.135)\end{array}$ & $\begin{array}{c}0.560^{* * *} \\
(0.198)\end{array}$ & $\begin{array}{l}-0.459 \\
(0.313)\end{array}$ & $\begin{array}{c}0.321 \text { *** } \\
(0.073)\end{array}$ \\
\hline SIZE & $\begin{array}{c}0.314^{* * * *} \\
(0.051)\end{array}$ & $\begin{array}{c}0.364 * * * \\
(0.045)\end{array}$ & $\begin{array}{c}0.356^{* * *} \\
(0.055)\end{array}$ & $\begin{array}{c}0.350^{* * *} \\
(0.057)\end{array}$ & $\begin{array}{c}0.321 * * * \\
(0.051)\end{array}$ & $\begin{array}{c}0.307 * * * \\
(0.053)\end{array}$ \\
\hline LR & $\begin{array}{l}-1.095 \\
(0.941)\end{array}$ & $\begin{array}{l}-0.999 \\
(0.844)\end{array}$ & $\begin{array}{l}-1.119 \\
(0.969)\end{array}$ & $\begin{array}{l}-0.223 \\
(0.760)\end{array}$ & $\begin{array}{l}-0.315 \\
(0.778)\end{array}$ & $\begin{array}{l}-0.223 \\
(0.782)\end{array}$ \\
\hline MQ & $\begin{array}{c}1.996^{* *} \\
(0.823)\end{array}$ & $\begin{array}{l}1.596^{* *} \\
(0.705)\end{array}$ & $\begin{array}{c}2.049 * * \\
(0.834)\end{array}$ & $\begin{array}{c}1.165 \\
(0.909)\end{array}$ & $\begin{array}{c}1.266 \\
(0.957)\end{array}$ & $\begin{array}{c}1.174 \\
(0.944)\end{array}$ \\
\hline CAP & $\begin{array}{l}-0.398 \\
(0.453)\end{array}$ & $\begin{array}{l}-0.553 \\
(0.405)\end{array}$ & $\begin{array}{l}-0.560 \\
(0.454)\end{array}$ & $\begin{array}{c}1.336^{* *} \\
(0.548)\end{array}$ & $\begin{array}{c}1.163 * * \\
(0.592)\end{array}$ & $\begin{array}{c}1.183^{* *} \\
(0.578)\end{array}$ \\
\hline $\mathrm{RD}$ & $\begin{array}{c}-0.430^{* * *} \\
(0.110)\end{array}$ & $\begin{array}{c}-0.474 * * * \\
(0.116)\end{array}$ & $\begin{array}{c}-0.492^{* * *} \\
(0.113)\end{array}$ & $\begin{array}{l}-0.070 \\
(0.103)\end{array}$ & $\begin{array}{l}-0.068 \\
(0.099)\end{array}$ & $\begin{array}{l}-0.040 \\
(0.096)\end{array}$ \\
\hline HHI & $\begin{array}{c}-4.461 * * * \\
(1.615)\end{array}$ & $\begin{array}{l}-1.225 \\
(1.415)\end{array}$ & $\begin{array}{c}-3.658^{* *} \\
(1.464)\end{array}$ & $\begin{array}{l}-2.125^{*} \\
(1.109)\end{array}$ & $\begin{array}{c}-2.276^{* *} \\
(1.145)\end{array}$ & $\begin{array}{c}-2.550^{* *} \\
(1.160)\end{array}$ \\
\hline LI & $\begin{array}{c}1.210 \\
(1.043)\end{array}$ & $\begin{array}{c}0.661 \\
(0.836)\end{array}$ & $\begin{array}{c}0.900 \\
(1.064)\end{array}$ & $\begin{array}{c}0.807 \\
(0.611)\end{array}$ & $\begin{array}{l}1.204^{*} \\
(0.717)\end{array}$ & $\begin{array}{c}1.141 \\
(0.695)\end{array}$ \\
\hline GDPG & $\begin{array}{c}-0.114^{*} \\
(0.061)\end{array}$ & $\begin{array}{l}-0.014 \\
(0.053)\end{array}$ & $\begin{array}{l}-0.081 \\
(0.054)\end{array}$ & $\begin{array}{l}-0.016 \\
(0.050)\end{array}$ & $\begin{array}{l}-0.020 \\
(0.047)\end{array}$ & $\begin{array}{l}-0.031 \\
(0.049)\end{array}$ \\
\hline INFL & $\begin{array}{c}-0.018^{*} \\
(0.010)\end{array}$ & $\begin{array}{l}-0.004 \\
(0.011)\end{array}$ & $\begin{array}{l}-0.014 \\
(0.010)\end{array}$ & $\begin{array}{l}-0.008 \\
(0.009)\end{array}$ & $\begin{array}{l}-0.010 \\
(0.008)\end{array}$ & $\begin{array}{l}-0.011 \\
(0.009)\end{array}$ \\
\hline GG & $\begin{array}{c}-1.014^{*} \\
(0.529)\end{array}$ & $\begin{array}{c}-0.801 * \\
(0.482)\end{array}$ & $\begin{array}{c}-1.302^{* *} \\
(0.528)\end{array}$ & $\begin{array}{l}-0.677 \\
(0.582)\end{array}$ & $\begin{array}{l}-0.695 \\
(0.531)\end{array}$ & $\begin{array}{l}-0.522 \\
(0.520)\end{array}$ \\
\hline County effect included & Yes & Yes & Yes & Yes & Yes & Yes \\
\hline Observations & 373 & 424 & 373 & 397 & 397 & 397 \\
\hline R-squared & 0.339 & 0.291 & 0.329 & 0.321 & 0.326 & 0.320 \\
\hline
\end{tabular}

This table displays the results of the relationship between banking stability and digital financial inclusion while controlling the bank-specific and macroeconomic variables using the panel-corrected standard errors (PCSE) method of Beck and Katz (1995), following Alfadli and Rjoub (2019). In this table, DFI, SIZE, LR, MQ, CAP, RD, HHI, LI, GDPG, INFL, GG refer to Digital financial inclusion index, Bank size, Loan ratio, Management quality, Capitalization, Revenue diversification, Herfindahl-Hirschman index, Lerner index, GDP growth, Inflation and Good Governance index respectively. Finally, *,**, and *** denote statistical significance at the $10 \%, 5 \%$, and $1 \%$ levels, respectively and Robust standard errors are in parenthesis. 


\begin{tabular}{|c|c|c|c|c|c|c|}
\hline & \multicolumn{3}{|c|}{ Ln(Sharp ratio) } & \multicolumn{3}{|c|}{ Ln(Z-score) } \\
\hline & (1) & (2) & (3) & (4) & (5) & (6) \\
\hline & DFI-Access & $\begin{array}{c}\text { DFI- } \\
\text { Usage }\end{array}$ & $\begin{array}{c}\text { DFI- } \\
\text { Overall }\end{array}$ & DFI-Access & $\begin{array}{l}\text { DFI- } \\
\text { Usage }\end{array}$ & $\begin{array}{c}\text { DFI- } \\
\text { Overall }\end{array}$ \\
\hline DFI & $\begin{array}{c}1.184^{* * *} \\
(0.410)\end{array}$ & $\begin{array}{l}-0.152 \\
(0.353)\end{array}$ & $\begin{array}{c}0.574 * * * \\
(0.134)\end{array}$ & $\begin{array}{c}0.439 * * * \\
(0.101)\end{array}$ & $\begin{array}{l}-0.253 \\
(0.524)\end{array}$ & $\begin{array}{c}0.255^{* * * *} \\
(0.027)\end{array}$ \\
\hline SIZE & $\begin{array}{c}0.294 * * * \\
(0.057)\end{array}$ & $\begin{array}{c}0.338^{* * *} \\
(0.049)\end{array}$ & $\begin{array}{c}0.339^{* * *} \\
(0.053)\end{array}$ & $\begin{array}{c}0.422^{* * *} \\
(0.119)\end{array}$ & $\begin{array}{c}0.388^{* * *} \\
(0.125)\end{array}$ & $\begin{array}{c}0.385^{* * *} \\
(0.134)\end{array}$ \\
\hline LR & $\begin{array}{l}-0.370 \\
(0.758)\end{array}$ & $\begin{array}{l}-0.276 \\
(0.662)\end{array}$ & $\begin{array}{l}-0.309 \\
(0.670)\end{array}$ & $\begin{array}{l}-0.393 \\
(0.663)\end{array}$ & $\begin{array}{l}-0.423 \\
(0.622)\end{array}$ & $\begin{array}{l}-0.294 \\
(0.649)\end{array}$ \\
\hline MQ & $\begin{array}{c}2.160^{* *} \\
(0.981)\end{array}$ & $\begin{array}{l}1.737 * \\
(0.923)\end{array}$ & $\begin{array}{l}1.753^{*} \\
(0.925)\end{array}$ & $\begin{array}{c}2.138^{* * *} * \\
(0.730)\end{array}$ & $\begin{array}{c}1.475^{* *} \\
(0.654)\end{array}$ & $\begin{array}{c}1.392 * * \\
(0.652)\end{array}$ \\
\hline CAP & $\begin{array}{l}-0.275 \\
(0.471)\end{array}$ & $\begin{array}{l}-0.418 \\
(0.462)\end{array}$ & $\begin{array}{l}-0.458 \\
(0.477)\end{array}$ & $\begin{array}{l}2.419^{*} \\
(1.424)\end{array}$ & $\begin{array}{c}2.082 \\
(1.500)\end{array}$ & $\begin{array}{c}2.145 \\
(1.462)\end{array}$ \\
\hline $\mathrm{RD}$ & $\begin{array}{l}-0.169 \\
(0.158)\end{array}$ & $\begin{array}{l}-0.181 \\
(0.134)\end{array}$ & $\begin{array}{l}-0.178 \\
(0.137)\end{array}$ & $\begin{array}{l}-0.057 \\
(0.090)\end{array}$ & $\begin{array}{c}0.007 \\
(0.075)\end{array}$ & $\begin{array}{c}0.026 \\
(0.077)\end{array}$ \\
\hline HHI & $\begin{array}{c}-3.901 * * * \\
(1.429)\end{array}$ & $\begin{array}{l}-0.330 \\
(1.223)\end{array}$ & $\begin{array}{l}-0.271 \\
(1.236)\end{array}$ & $\begin{array}{c}-3.014 * * * \\
(1.082)\end{array}$ & $\begin{array}{c}0.221 \\
(1.597)\end{array}$ & $\begin{array}{c}0.112 \\
(1.593)\end{array}$ \\
\hline LI & $\begin{array}{c}1.027 \\
(1.079)\end{array}$ & $\begin{array}{c}0.479 \\
(0.874)\end{array}$ & $\begin{array}{c}0.567 \\
(0.905)\end{array}$ & $\begin{array}{c}1.007 \\
(0.889)\end{array}$ & $\begin{array}{c}0.862 \\
(0.774)\end{array}$ & $\begin{array}{c}0.807 \\
(0.857)\end{array}$ \\
\hline GDPG & $\begin{array}{c}-0.099 * * \\
(0.047)\end{array}$ & $\begin{array}{l}-0.005 \\
(0.041)\end{array}$ & $\begin{array}{l}-0.003 \\
(0.041)\end{array}$ & $\begin{array}{l}-0.028 \\
(0.045)\end{array}$ & $\begin{array}{l}-0.012 \\
(0.039)\end{array}$ & $\begin{array}{l}-0.018 \\
(0.040)\end{array}$ \\
\hline INFL & $\begin{array}{l}-0.012 \\
(0.009)\end{array}$ & $\begin{array}{l}-0.002 \\
(0.009)\end{array}$ & $\begin{array}{l}-0.002 \\
(0.009)\end{array}$ & $\begin{array}{l}-0.003 \\
(0.011)\end{array}$ & $\begin{array}{l}-0.005 \\
(0.010)\end{array}$ & $\begin{array}{l}-0.005 \\
(0.011)\end{array}$ \\
\hline GG & $\begin{array}{c}-1.109 * \\
(0.621)\end{array}$ & $\begin{array}{c}-0.958^{*} \\
(0.532)\end{array}$ & $\begin{array}{c}-1.038^{*} \\
(0.536)\end{array}$ & $\begin{array}{c}-1.141 * \\
(0.592)\end{array}$ & $\begin{array}{c}-0.771 * \\
(0.456)\end{array}$ & $\begin{array}{l}-0.621 \\
(0.457)\end{array}$ \\
\hline County effect included & Yes & Yes & Yes & Yes & Yes & Yes \\
\hline Observations & 373 & 424 & 424 & 397 & 447 & 447 \\
\hline $\mathrm{R}^{2}$ & 0.3197 & 0.2690 & 0.2658 & 0.3086 & 0.2538 & 0.2490 \\
\hline
\end{tabular}

This table displays the results of the relationship between banking stability and digital financial inclusion while controlling the bank-specific and macroeconomic variables using the Two-Stage Panel Least Squares Instrumental Variables (2SLS-IV) method, following Kim et al. (2020) for the robustness of the results. In this table, DFI, SIZE, LR, MQ, CAP, RD, HHI, LI, GDPG, INFL, GG refer to Digital financial inclusion index, Bank size, Loan ratio, Management quality, Capitalization, Revenue diversification, Herfindahl-Hirschman index, Lerner index, GDP growth, Inflation and Good Governance index respectively. Finally, *, **, and *** denote statistical significance at the $10 \%, 5 \%$, and $1 \%$ levels, respectively and Standard errors are in parenthesis. 
$\underline{\text { Table V: DFI and Islamic banking stability by size }}$

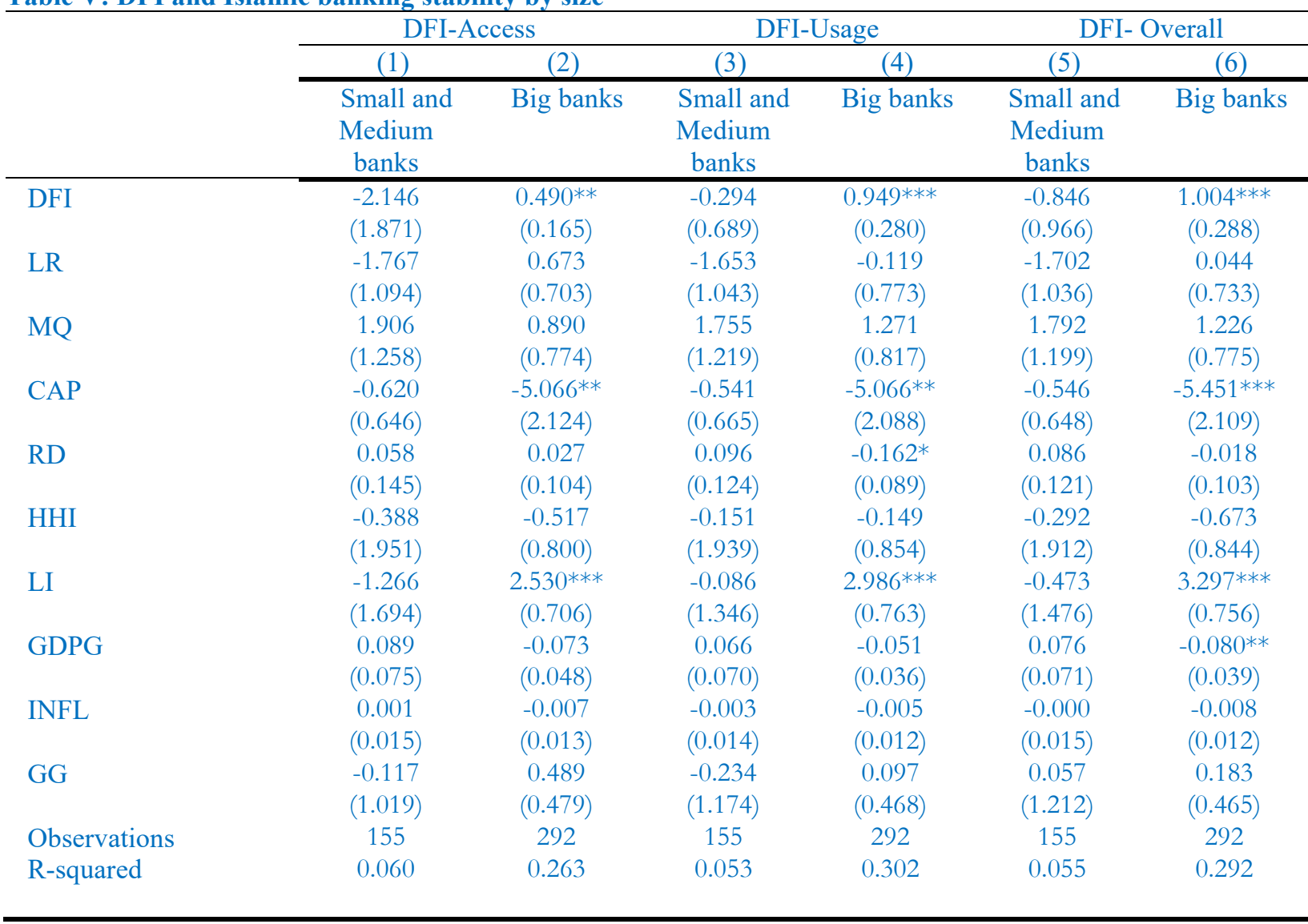

This table displays the results of the relationship between banking stability and digital financial inclusion by splitting sample based on bank size for the robustness of the results. In this table, DFI, LR, MQ, CAP, RD, HHI, LI, GDPG, INFL, GG refer to Digital financial inclusion index, Loan ratio, Management quality, Capitalization, Revenue diversification, Herfindahl-Hirschman index, Lerner index, GDP growth, Inflation and Good Governance index respectively. Finally, ***, and *** denote statistical significance at the 10\%, 5\%, and $1 \%$ levels, respectively and Standard errors are in parenthesis. 


\begin{tabular}{|c|c|c|c|c|c|}
\hline & \multicolumn{2}{|c|}{$\begin{array}{c}\text { Panel A: Alternative DFI- } \\
\text { MORDIGPAY }\end{array}$} & \multicolumn{3}{|c|}{ Panel B: Alternative Bank Stability- NPLs } \\
\hline & (1) & (2) & (3) & (4) & (5) \\
\hline & LSHARP & $\overline{\mathrm{LZS}}$ & DFI-Access & DFI-Usage & $\begin{array}{c}\text { DFI- } \\
\text { Overall }\end{array}$ \\
\hline DFI & $\begin{array}{c}2.121 * * * \\
(0.789)\end{array}$ & $\begin{array}{l}1.481^{* *} \\
(0.642)\end{array}$ & $\begin{array}{c}-0.185^{* *} \\
(0.091)\end{array}$ & $\begin{array}{c}-0.188^{* *} \\
(0.074)\end{array}$ & $\begin{array}{c}-0.402 * * * \\
(0.117)\end{array}$ \\
\hline SIZE & $\begin{array}{c}0.299 * * * \\
(0.054)\end{array}$ & $\begin{array}{c}0.272^{* * *} \\
(0.065)\end{array}$ & $\begin{array}{c}-0.046^{* * *} \\
(0.006)\end{array}$ & $\begin{array}{c}-0.047 * * * \\
(0.006)\end{array}$ & $\begin{array}{c}-0.046 * * * \\
(0.006)\end{array}$ \\
\hline LR & $\begin{array}{l}-1.397^{*} \\
(0.801)\end{array}$ & $\begin{array}{l}-0.592 \\
(0.597)\end{array}$ & $\begin{array}{l}-0.076 \\
(0.084)\end{array}$ & $\begin{array}{l}-0.085 \\
(0.084)\end{array}$ & $\begin{array}{l}-0.081 \\
(0.083)\end{array}$ \\
\hline MQ & $\begin{array}{c}1.784 * * * \\
(0.689)\end{array}$ & $\begin{array}{c}0.825 \\
(0.662)\end{array}$ & $\begin{array}{l}-0.219 \\
(0.215)\end{array}$ & $\begin{array}{l}-0.181 \\
(0.215)\end{array}$ & $\begin{array}{l}-0.177 \\
(0.211)\end{array}$ \\
\hline CAP & $\begin{array}{l}-0.530 \\
(0.438)\end{array}$ & $\begin{array}{c}0.911 \\
(0.649)\end{array}$ & $\begin{array}{c}-0.432 * * * \\
(0.048)\end{array}$ & $\begin{array}{c}-0.451 * * * \\
(0.050)\end{array}$ & $\begin{array}{c}-0.430 * * * \\
(0.047)\end{array}$ \\
\hline $\mathrm{RD}$ & $\begin{array}{c}-0.452^{* * *} \\
(0.113)\end{array}$ & $\begin{array}{l}-0.051 \\
(0.095)\end{array}$ & $\begin{array}{l}-0.009 \\
(0.013)\end{array}$ & $\begin{array}{l}-0.007 \\
(0.013)\end{array}$ & $\begin{array}{l}-0.007 \\
(0.013)\end{array}$ \\
\hline HHI & $\begin{array}{l}-1.318 \\
(1.907)\end{array}$ & $\begin{array}{c}0.727 \\
(1.442)\end{array}$ & $\begin{array}{c}-0.256^{*} \\
(0.137)\end{array}$ & $\begin{array}{l}-0.217 \\
(0.132)\end{array}$ & $\begin{array}{l}-0.210 \\
(0.133)\end{array}$ \\
\hline LI & $\begin{array}{c}0.582 \\
(1.053)\end{array}$ & $\begin{array}{l}1.516^{*} \\
(0.851)\end{array}$ & $\begin{array}{l}-0.134 \\
(0.232)\end{array}$ & $\begin{array}{c}0.082 \\
(0.205)\end{array}$ & $\begin{array}{l}-0.446^{*} \\
(0.254)\end{array}$ \\
\hline GDPG & $\begin{array}{l}-0.029 \\
(0.057)\end{array}$ & $\begin{array}{l}-0.050 \\
(0.056)\end{array}$ & $\begin{array}{l}-0.003 \\
(0.004)\end{array}$ & $\begin{array}{l}-0.004 \\
(0.004)\end{array}$ & $\begin{array}{c}0.002 \\
(0.005)\end{array}$ \\
\hline INFL & $\begin{array}{l}-0.008 \\
(0.011)\end{array}$ & $\begin{array}{l}-0.017 \\
(0.011)\end{array}$ & $\begin{array}{c}-0.003^{* *} \\
(0.001)\end{array}$ & $\begin{array}{c}-0.003 * * \\
(0.001)\end{array}$ & $\begin{array}{l}-0.002 \\
(0.001)\end{array}$ \\
\hline GG & $\begin{array}{c}-2.513^{* * *} \\
(0.717)\end{array}$ & $\begin{array}{c}-1.209^{*} \\
(0.702)\end{array}$ & $\begin{array}{c}0.196 \\
(0.170)\end{array}$ & $\begin{array}{c}0.387^{* *} \\
(0.186)\end{array}$ & $\begin{array}{c}0.434^{* *} \\
(0.182)\end{array}$ \\
\hline $\begin{array}{l}\text { County effect } \\
\text { included }\end{array}$ & Yes & Yes & Yes & Yes & Yes \\
\hline Obs. & 391 & 410 & 302 & 302 & 302 \\
\hline $\mathrm{R}^{2}$ & 0.251 & 0.249 & 0.621 & 0.626 & 0.633 \\
\hline
\end{tabular}

This table displays the results of the relationship between banking stability and alternative digital financial inclusion while controlling the bank-specific and macroeconomic variables for the robustness of the results. In this table, MORDIGPAY, SIZE, LR, MQ, CAP, RD, HHI, LI, GDPG, INFL, GG refer to Made or received digital payments in the past year (\% age $15+)$, Bank size, Loan ratio, Management quality, Capitalization, Revenue diversification, Herfindahl-Hirschman index, Lerner index, GDP growth, Inflation and Good Governance index respectively. Finally, *,**, and *** denote statistical significance at the $10 \%, 5 \%$, and $1 \%$ levels, respectively 